\title{
Graft of Small Patch of Partial Thickness in Equine Wound
}

\author{
William Del Conte Martins ${ }^{1,3}$, Denis Steiner ${ }^{1}$, Arthur Borges Neto', Salviano Tramontin Belettini', \\ Carla Faria Orlandini' ', André Giarola Boscarato', Igor Bueno Volpato² \& Luiz Romulo Alberton'
}

Background: Cutaneous wounds in locomotor limbs represent one of the most frequent disorders in equine medicine. Wounds in equines are distinguished from those in other species by unique characteristics, including different healing rates among breeds, wound location and high propensity to formation of exuberant granulation tissue during the healing process. The wound healing process that cannot be sutured can be accelerated by the use of skin grafts, lowering the treatment cost. The objective of this report was to divulgate the success upon treatment of an extensive lacerated wound in the metatarsal region of a horse using autologous skin grafts.

Case: A 3-year-old, female, American quarter horse weighting $450 \mathrm{~kg}$ was brought to veterinary hospital with lower limb injury. According to the owner's report, the animal had one of its limbs stuck in a plain wire fence. A wound was observed in the metatarsal region during physical examination, the lesion caused an extensive skin laceration that showed the dorsal surface of the metatarsal bone and the digital extensor tendon. After injury assessment, wound debridement was carried out by surgery intervention followed by antisepsis and application of autologous plasma every two days as post-surgical care and wound preparation to receive the graft. Forty-five days after the first intervention, grafts were collected from the neck and implanted in the wound. The procedure achieved $70 \%$ of success. After approximately 75 days, transplantation was performed in other regions of the wound using the same technique. The duration of treatment at the Veterinary Hospital of the Universidade Paranaense (UNIPAR) was eight months, and then the animal returned home, where dressings were applied for two months to avoid the risk of contamination and until complete recovery.

Discussion: The debridement of the wound and edges approximation were of great value in order to begin the process of wound granulation. The established therapy with scarring with gauze and use of antiseptics only in the initial stages of treatment, the frequent exchange of bandages every two days, preventing the accumulation of exudate and the use of autologous plasma favored the formation of the granulation bed and was sufficient to avoid infection and the formation of exuberant granulation tissue. Factors such as excessive movement and local infection were also attributed as responsible for the longer healing period, so the use of the spring coupled to the horseshoe decreased the joint movement, proving to be effective in patients with severe extensor tendon lacerations. The use of the spring coupled to the horseshoe promoted a correct biomechanical alignment and no walking complication or deficiency was observed. The correct anatomical structural positioning prevents the formation of flexural deformities and fibrosis of the joint capsule. The use of micrografts was beneficial and simple to perform and the use of grafts contributed to a better cosmetic result. The main factor contributed to the grafting success was the use of dressing, which was regularly changed, and topical antimicrobial therapy correctly applied to avoid contamination. Based on the clinical result of this patient, it was concluded that the use of small autologous grafts can provide good recovery and healing of extensive wounds in horses when proper care with dressings and antimicrobial medication is provided after surgical interventions.

Keywords: equine, surgery, graft, healing. 


\section{INTRODUCTION}

The wounds represent one of the most frequent disorders of equine medicine, due to the horse's nature and environment where it lives, which contributes to the appearance of cutaneous trauma [7]. The wounds that are localized in the distal portion of the member with great loss of cutaneous tissue represent a differentiated problem due to the formation of granulation tissue. Factors that may be related to the formation of granulation tissue include: intensive movement, lack of soft tissue for coverage, excessive contamination and reduced irrigation in the healing site [14].

The healing process comprises numerous phases, whose purpose is the replacement of damaged tissue by a new vascularized connective tissue, independent of the nature of the lesion [13]. Wounds in equines are distinguished from other species by unique characteristics, including different healing rates between breeds [17], wound location and great propensity to formation of exuberant granulation tissue during cicatrisation process [8].

The healing process in wounds that cannot be sutured can be accelerated by use skin grafts, which may also provide lower costs in the treatment [11]. The skin grafts are classified as free grafts or pedicle grafts. Free grafts are more commonly used in the equine species, because the small elasticity of the skin limits the application of the pedicle grafts [18]. Among free grafts, various methods are viable, including the grafts with total thickness, partial and mesh grafts [12]. Therefore, the objective of this work is to report the success upon treatment of an extensive lacerated wound on the metatarsus of an equine with the use of autologous graft in pouch.

\section{CASE}

A 3-year-old, female, American quarter horse weighting $450 \mathrm{~kg}$ with and leg injury was brought to UNIPAR Veterinary Hospital. According owner's report, the animal has its legs stuck in a plain wire fence. During the physical examination a lesion was observed in the metatarsal region with extensive skin laceration that make possible to see the digital extensor tendon and the dorsal surface of metatarsal bone (Figure 1).

Due to the severity of the lesion, surgical intervention was carried out (Figure 2). Anaesthesia was performed with guaifenesin ${ }^{1}(100 \mathrm{mg} / \mathrm{kg}$, IV), xylazine $^{2} 10 \%(1 \mathrm{mg} / \mathrm{kg}, \mathrm{IV})$ and ketamine ${ }^{3} 10 \%$ (1 $\mathrm{mg} / \mathrm{kg}, \mathrm{IV})$, diluted in a $5 \%$ glucose $\mathrm{e}^{4}$ solution (500 $\mathrm{mL}$ ) all administered IV as pre aesthetic medication and also for induction of general anaesthesia. After oro-tracheal intubation anaesthesia was maintained with isoflurane ${ }^{5}$ vaporized in oxygen and animal was positioned in lateral recumbency for the surgical procedure. After the surgery, the animal was medicated treated with procaine benzyl penicillin ${ }^{6}(10.000 \mathrm{UI} / \mathrm{kg}$, IM, q24h), streptomycin ${ }^{5}$ sulphate ( $5 \mathrm{mg} / \mathrm{kg}$ IM, q24h) during ten days, and flunixin meglumine ${ }^{7}(1.1 \mathrm{mg} / \mathrm{kg}$, IM, q12h) during five days. The purpose of surgery was to remove necrotic tissue, promote revitalization and approximation of the wound to accelerate tissue repair. The suture was performed involving skin and subcutaneous tissue with nylon-4 in an interrupted horizontal mattress suture to approximate the wound edges.

After the surgery, the animal was monitored until complete anaesthetic recovery. A spring was then used to aid movement of the cranial phase of the animal's step, preventing hyperflexion of fetlock and favouring healing of the distal stump of the wound involving skin and digital extensor tendon, and avoiding periarticular trauma (Figure 3).

A horseshoe adapted with a protrusion in the region of the toe was also used with a hole so that the spring could be fixed. In the dorsal part was put a handle of limbs, for fixation of the spring. The spring was maintained for 45 days, until the formation of fibrous tissue.

The first dressing replacement was performed three days after surgery. The wound was cleaned with sodium chloride physiological solution, iodine povidone (PVPI) and hydrogen peroxide. After the first exchange, the patient was treated daily for ten days. On the 14th day after surgery the wound was treated with autologous blood plasma. To obtain the plasma, the blood was collected in a $500 \mathrm{~mL}$ double collector bag with a $400 \mathrm{~mL}$ satellite bag. After separation of the plasma, this material was kept into the satellite bag in the refrigerator for maintenance. The contents of one plasma bag were sufficient for approximately two weeks of treatment; this technique was performed during 40 days. The dressing was changed every two days to clean the wound and application of the plasma soaked in gauze (Figure 4), and then the bandage was performed. The result of the treatment with blood plasma was satisfactory, inducing to ideal condition of the site in order to receive the graft (Figure 5). 
Fifty-five days after the first procedure, a surgical procedure was performed the skin graft. The graft procedure of small partial-thickness flaps was started using the technique described by Hendrickson [5]. For this, the partial thickness fragments were removed from the neck region of the animal. The hair clipping and preoperative antisepsis on the left cervical region of the horse were performed, the animal was sedated with xylazine $10 \%(1 \mathrm{mg} / \mathrm{kg}$, IV) and local infiltrative anaesthesia with lidocaine ${ }^{6} 2 \%(10 \mathrm{~mL})$ without vasoconstrictor was injected.

The tissue to be used was removed from the donor bed with Adson's forceps and a No. 15 scalpel, left in Ringer's solution with sodium lactate ${ }^{8}$, maintained at $37.5^{\circ} \mathrm{C}$ until transplantation was begun. The donor site was sutured with nylon-1, and applied topically ointment paste (permethrin + zinc oxide). The wound was then cleaned with iodine povidone to start transplantation; the technique used for transplantation was in a bag, where the skin fragments were implanted with the epithelium portion upwards.

A scalpel with blade $n .15$ was used to prepare the site to receive the graft. After the procedure a dressing was performed using ointment with $0.5 \mathrm{~g}$ of gentamicin sulphate, $5.0 \mathrm{~g}$ of sulphanilamide, urea $5.0 \mathrm{~g}$ and vitamin A $120,000 \mathrm{IU}^{9}$, to avoid contamination in the site (Figure 6). There was a 70\% success in implantation of the grafts in the first week; however, some had to be re-implanted due to humidity, temperature and also skin rejection. After approximately 75 days, the transplants were performed in other regions of the wound using the same technique. The duration of treatment at the UNIPAR Veterinary Hospital was eight months, after that the animal returned home, where dressings were applied to avoid contamination during two months until total recovery of the animal (Figure 7).

\section{DISCUSSION}

The debridement of the wound and edges approximation were of great value in order to begin the process of wound granulation, corroborating with the observations of Dart et al. [2] since in the initial periods the debridement affects healing in a positive way reducing the number of bacteria, debris, soiling and rates of devitalized tissues, which would otherwise need to be removed by cellular inflammation, thereby reducing the inflammatory period. One of the factors that contributes to late healing or re-epithelialization of the wound is the exuberant granulation tissue that has a complex formation pathway and several interfering factors, one of the main ones being wound contamination [4].

The established therapy with every two days cleaning of the wound and application of the plasma

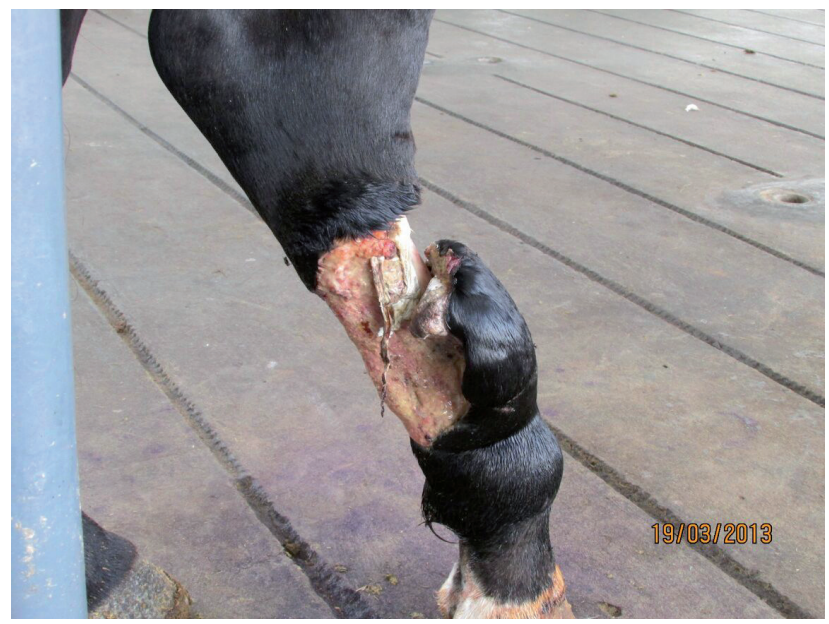

Figure 1. Image of the equine metatarsal region showing skin, tendon and periosteal lesion.

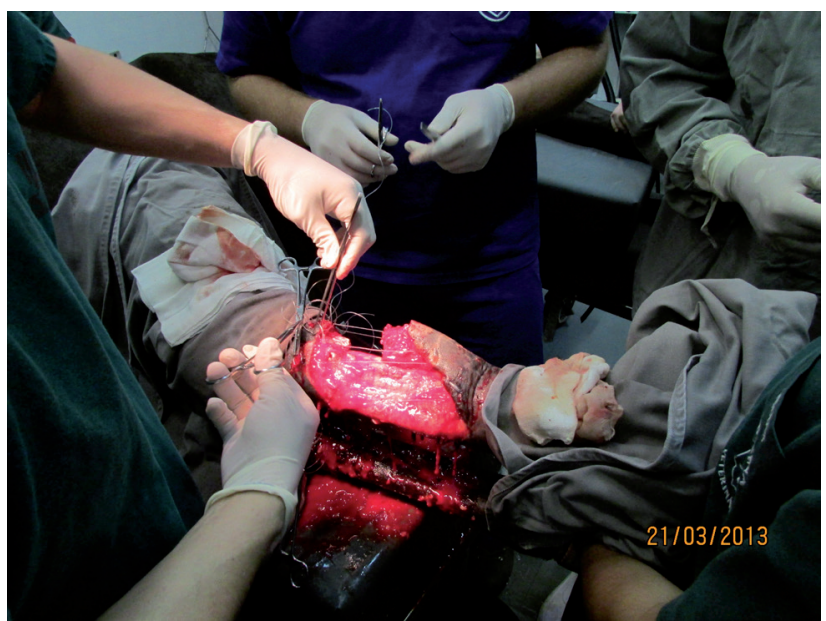

Figure 2. Showing the surgery procedure to remove necrotic tissue, promote revitalization and approximation of the wound.

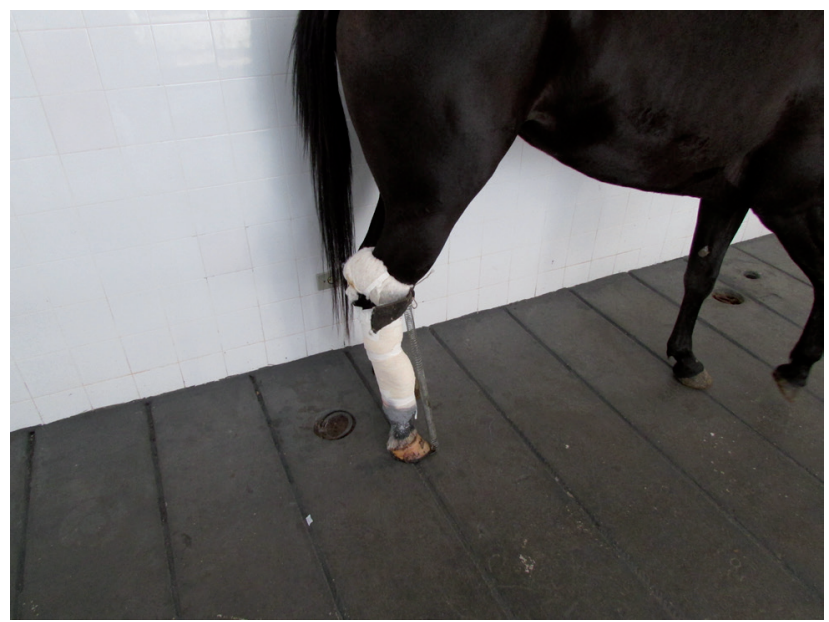

Figure 3. Image of spring fixed in horseshoe preventing hyperflexion of fetlock. 
and bandage favoured the formation of the granulation bed and was sufficient to avoid infection as well as the formation of exuberant granulation tissue. The use of plasma was reported by some authors $[9,15,16]$ in order to stimulate growth factors in high concentrations at the site where recover tissue injuries leading to acceleration of the healing process. In this study, it was easy to obtain the plasma and then using it, induced the acceleration of the healing process and granulation tissue formation process The sedimentation technique

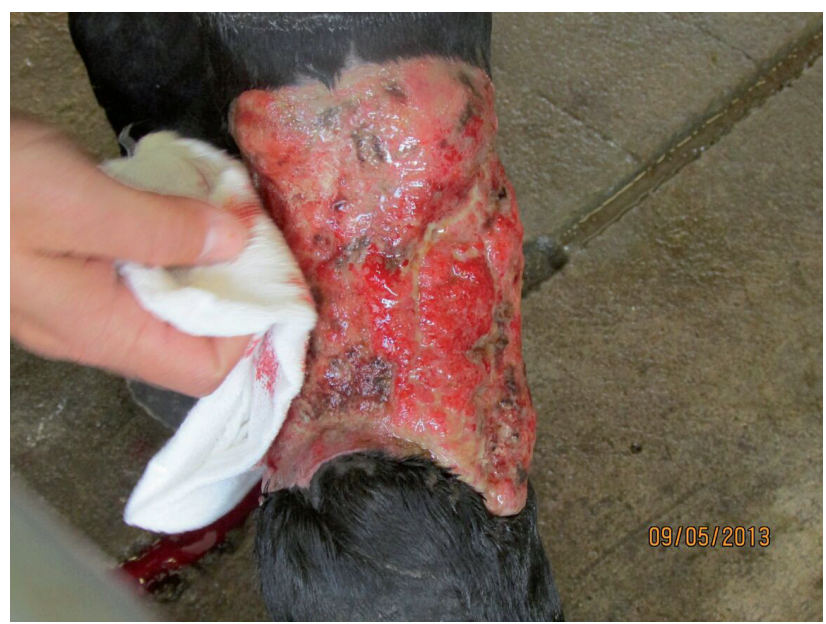

Figure 4. Image of the wound in the metatarsal region of the animal being performed the dressing.

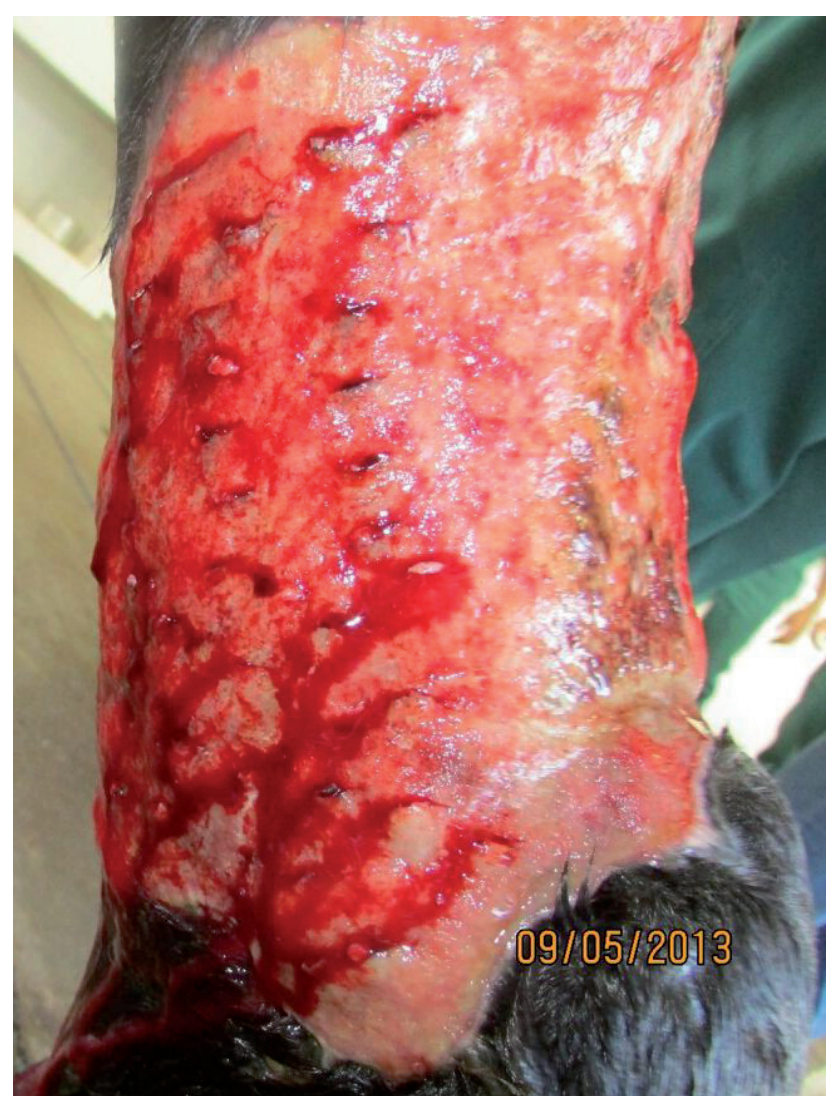

Figure 5. Metatarsal region after 45 days of surgery, showing satisfactory evolution.

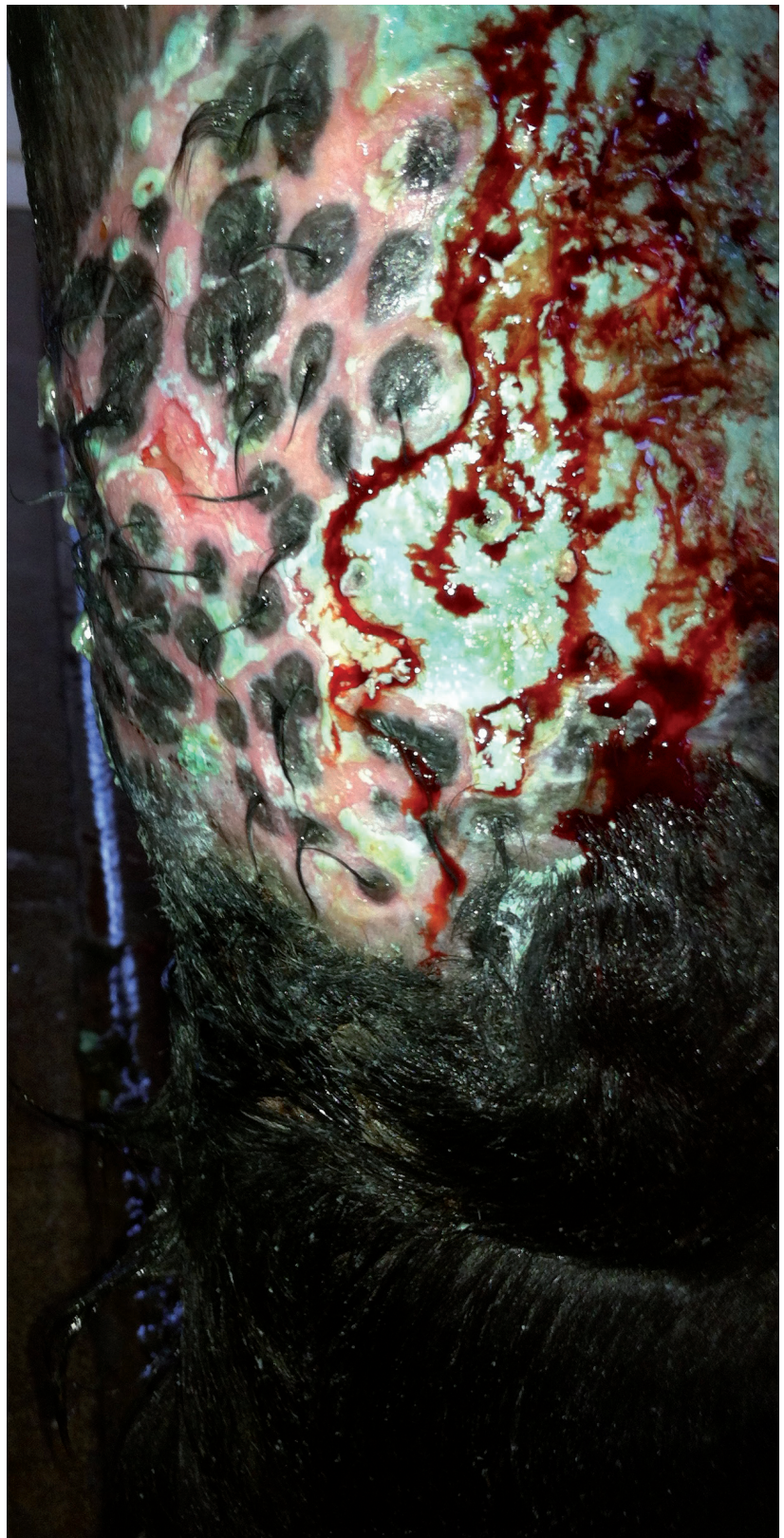

Figure 6. Showing the wound bed after graft surgery.

was used as a function of ease, and there are other ways to obtain the blood plasma, either by centrifugation or apheresis. Certainly this process induced the formation of a viable bed to receive the implant.

The use of bandages has beneficial effects such as reduction of contamination, protection of primordial structures and provides mechanical stabilization, although it may lead to formation of exuberant granulation tissue by vascular micro occlusion and focal hypoxia [1], but a moist environment provided through occlusion contact seems to promote conditions more conducive to tissue repair $[6,19]$, providing a regulated and thermally constant environment [3], a fact observed during the tissue repair process in this study. 


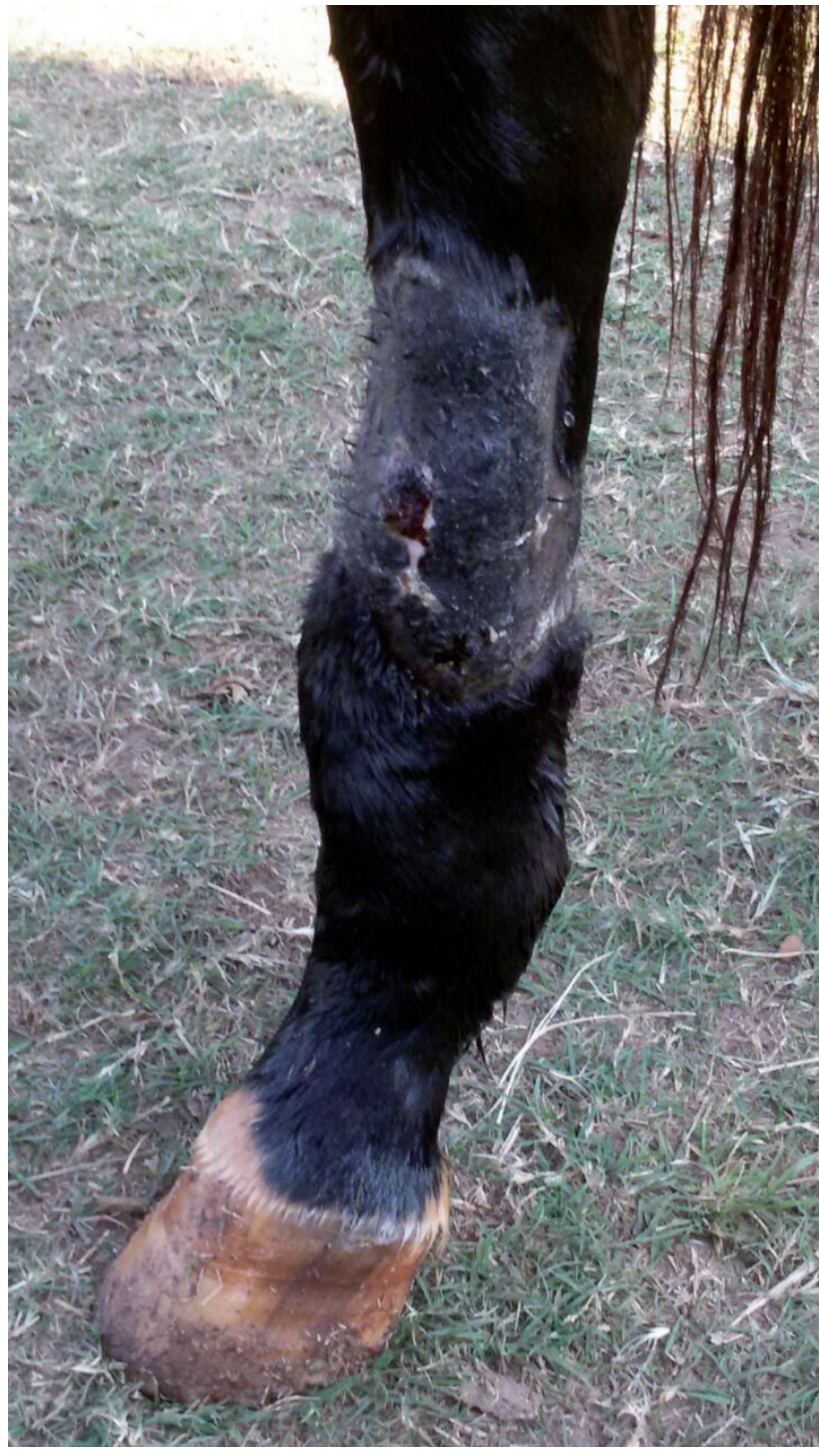

Figure 7. Image of the wound, after 10 months, showing hair growth at the site of skin grafts

Although it was expected observation of the exuberant granulation tissue paradoxically only minor complications were noticed. Scarring with gauze and the use of antiseptics only in the initial stages of treatment [6], the frequent exchange of bandages preventing the accumulation of exudate [1] and the use of autologous plasma [15] appear to have attenuated this process.

Factors such as excessive movement and local infection were also attributed as responsible for a longer healing period, so the use of the spring coupled to the horseshoe decreased the movement of the joint, proving to be effective in patients with severe extensor tendon lacerations. The use of the spring coupled to the toe promoted a correct biomechanical alignment and no complication or deficiency in walking was observed. The correct anatomical structural positioning prevents the formation of flexural deformities and fibrosis of the joint capsule [14]. Although this author mentioned that the provisional use of polyvinyl chloride (PVC) splints in order to promote the stability of the metacarpophalangeal joint to the formation of fibrous tissue, although practices and simple execution promote skin lesions by pressure [14], which did not occur in this work.

The use of micrografts was beneficial and simple to perform. Adherence and revascularization rates close to $70 \%$ were higher than the mean values in the literature [8]. The adequate preparation of the wound and a healthy and vascularized granulation tissue, the correct use of bandages that favour the formation of a humid environment and the absence of contamination are correlated with the success of the procedure [8]. Therefore, the preparation of the receptor bed is of great importance to ensure the viability of the grafts [18].

The choice of the cervical region as a donor bed presented conveniences such as easy surgical access and the possibility of being performed with the animal standing, only under sedation and infiltration with local anaesthetics. In addition, the small scars observed during the process of repair of the donor bed were covered by mane of the animal. The procedure performed with the animal standing is beneficial, as there is no need for general anaesthetics that make the procedure more expensive and negative intercurrences may occur in aesthetic recovery using general anaesthetics. The use of sedation and local infiltrative anaesthesia reduced costs and time of postoperative aesthetic recovery.

The main factor contributed to the success of the graft were dressing, which was changed regularly, and topical antimicrobial therapy applied correctly to avoid contamination of the site. The care performed is in agreement with those cited by Paganela et al. [7]. The benefits of using topical antimicrobial corroborated with another study that discusses the greater effectiveness and higher therapeutic concentration of the drug in granulation tissue when compared to systemic use [10].

The use of the grafts contributed to a better cosmetic result. The treatment of lacerative lesions of the tendons involves surgical intervention and post-surgical rehabilitation, because of the complexity, the location of the wound and the involved tissue [20].

It is concluded based on the clinical result of this patient that the use of grafts of small partial-thickness flaps can provide good recovery and healing 
of extensive wounds in horses, provided that due care is taken in the postoperative period in relation to dressings and antimicrobial medication. This technique can be performed without the use of general anaesthetics and is therefore applicable by veterinarians who treat horses in regions where there is no hospital structure available.

\section{MANUFACTURERS}

${ }^{1}$ Henrifarma Produtos Químocos e Farmacêuticos Ltda. São Paulo, SP, Brazil.

${ }^{2}$ Konig do Brasil Ltda. São Paulo, SP, Brazil.

${ }^{3}$ Agener União Saúde Animal. Embu-Guaçu, SP, Brazil.

${ }^{4}$ Eurofarma Laboratórios S.A. Ribeirão Preto, SP, Brazil.

${ }^{5}$ Cristália Produtos Químicos Farmacêuticos Ltda. Itapira, SP, Brazil.

${ }^{6}$ Zoetis Indústria de Produtos Veterinários Ltda. Guarulhos, SP,
Brazil.

${ }^{7}$ Jofadel Indústria Farmacêutica AS. Varginha, MG, Brazil.

${ }^{8}$ Equiplex Indústria Farmacêutica. Aparecida de Goiânia, GO,

Brazil.

${ }^{9}$ Chemitec Agro Veterinária. São Paulo, SP, Brazil.

Acknowledgements. We would like to thank the Veterinary Hospital of the Universidade Paranaense and Graduate Program in Animal Science of the Universidade Paranaense, Brazil. Also we would like to thank the Coordenação de Aperfeiçoamento de Pessoal de Ensino Superior (CAPES) for funding the Programa de Suporte à Pós-Graduação de Instituições de Ensino Superior Particulares (PROSUP).

Declaration of interest. None of the authors of this paper has a financial or personal relationship with other people or organisations that could inappropriately influence or bias the content of the paper

\section{REFERENCES}

1 Berry D.B. 2nd \& Sullins K.E. 2003. Effects of topical application of antimicrobials and bandaging on healing and granulation tissue formation in wounds of the distal aspect of the limbs in horses. American Journal Veterinary Research. 64(1): 88-92.

2 Dart A.J., Dowling B.A. \& Smith C.L. 2005. Topical treatments in equine wound management. Veterinary Clinics of North America: Equine Practice. 21(1):77-89.

3 Ducharme-Desjarlais M., Céleste C.J., Lepault E. \& Theoret C.L. 2005. Effect of a silicone-containing dressing on exuberant granulation tissue formation and wound repair in horses. American Journal Veterinary Research. 66(7): 1133-1139.

4 Harmon C.C.G., Hawkins J.F., Li J., Connell S., Miller M., Saenger M. \& Freeman L.J. 2017. Effects of topical application of silver sulfadiazine cream, triple antimicrobial ointment, or hyperosmolar nanoemulsion on wound healing, bacterial load, and exuberant granulation tissue formation in bandaged full-thickness equine skin wounds. American Journal Veterinary Research. 78(5): 638-646

5 Hendrickson D.A. 2013. Reconstructive surgery of wounds. In: Hendrickson D.A. \& Baird N.A. (Eds). Turner and McIlwraith's Techniques in Large Animal Surgery. 4th edn. Ames: Wiley Blackwell, pp.103-110.

6 Hendrickson D.A. 2006. Management of deep and chronic wounds. In: Auer J.A. \& Stick J.A. (Eds). Equine surgery. 3rd edn. St. Louis: Saunders Elsevier, pp.288-298.

7 Paganela J.C., Ribas L.M., Santos C.A., Feijó L.S., Nogueira C.E.W. \& Fernandes C.G. 2009. Abordagem clínica de feridas cutâneas em equinos. Revista Portuguesa de Ciências Veterinárias. 104: 13-18

8 Provost P. 2012. Wound healing. In: Auer J.A. \& Stick J.A. (Eds). Equine Surgery. 4th edn. St Louis: Saunders, pp.47-61.

9 Ribeiro S.N., Atallah F.A., Taffarel M.O., Salgado A.E.P., Melo-Filho E.V., Beletti M.E., Freitas P.M.C. \& Oliveira A.L.A. 2013. Plasma rico em plaquetas como curativo em queimaduras de espessura total em coelhos. Revista Brasileira de Medicina Veterinária. 35(Suppl 1): 79-83.

10 Schumacher J. 2012. Wounds of the distal portion of the limb. In: Kentucky veterinary medical association. Fonte:<http://c.ymcdn.com/sites/www.kvma.org/resource/resmgr/imported/1-09-Wounds\%20of\%20the\%20Distal\%20 Portion\%20of\%20the\%20Limb.pdf>. [Accessed online in December 2016].

11 Schumacher J. 2006. Skin grafting. In: Auer J.A. \& Stick J.A. (Eds). Equine Surgery. 3rd edn. St. Louis: Elsevier Saunders, pp.269-288.

12 Schumacher J. 2015. Practical techniques of skin grafting horses that you can perform in your practice. In: American Association of Equine Practioners Annual Meeting. Proceedings. 2015. Fonte:<http://files.eventsential.org/b6a3b65af39c-4146-ae3a-c5737f59fefb/event-576/91393740-Schumacher\%20-\%20Practical\%20Techniques.pdf>. [Accessed online in September 2016]. 
13 Soo C., Sayah D.N., Zhang X., Beanes S.R., Nishimura I., Dang C., Freymiller E. \& Ting K. 2002. The identification of novel wound-healing genes through differential display. Plastic and Reconstructive Surgery. 110 (3): $787-789$.

14 Stashak T.S. 1994. Manejo de las heridas en Equinos. Buenos Aires: Intermedica, 236p.

15 Vendramim F.S., Franco D. \& Franco T.R. 2010. Utilização do plasma rico em plaquetas autólogo nas cirurgias de enxertos cutâneos em feridas crônicas. Revista Brasileira Cirurgia Plástica. 25(4): 589-94

16 Vendruscolo C.P., Watanabe M.J., Maia L., Carvalho A.M. \& Alves A.L.G. 2012. Plasma rico em plaquetas: uma nova perspectiva terapêutica para medicina equina. Veterinária e Zootecnia. 19(1): 33-43.

17 Wilmink J.M., Van Weeren P.R., Stolk P.W., Van Mil F.N. \& Barneveld A. 1999. Differences in second-intention wound healing between horses and ponies: histological aspects. Equine Veterinary Journal. 31(1): 61-67.

18 Wilson D.G. 1990 Applications of skin grafting in large animals. Problems Veterinary Medicine. 2(3): $442-462$.

19 Wright J.B., Lam K., Buret A.G., Olson M.E. \& Burrell R.E. 2002. Early healing events in a porcine model of contaminated wounds: effects of nanocrystalline silver on matrix metalloproteinases, cell apoptosis, and healing. Wound Repair Regeneration. 10(3): 141-51.

20 Yamada A.L.M., Alves A.L.G., Hussni C.A., Watanabe M.J., Carvalho A.M. \& Oliveira P.G.G. 2011. Células mononucleares da medula óssea no tratamento da ruptura total dos tendões flexores e ligamento suspensor do boleto em eqüino. Arquivo Brasileiro de Medicina Veterinária e Zootecnia. 63(6):1579-1582. 